DOI: https://doi.org/10.24144/2409-6857.2018.1(51).292-297

УДК 65.012.8

\author{
Шинкар С.М.
}

\title{
ПРОГНОЗУВАННЯ ЗМІНИ ЕКОНОМІЧНОЇ БЕЗПЕКИ ПІДПРИЕМСТВ НАФТОГАЗОВОЇ ПРОМИСЛОВОСТІ
}

\begin{abstract}
Поточна ситуачія для діяльності підприємств нафтогазової промисловості характеризується посиленням негативного впливу зовнішнього середовища та складністю контролю за внутрішніми процесами. Забезпечення необхідного рівня економічної безпеки потребує на основі оцінки ї̈ рівня прогнозування зміни під впливом ключових внутрішніх та зовнішніх загроз. Запропоновано методичне забезпечення формування реалістичного, песимістичного та оптимістичного прогнозів як основи для розроблення та реалізації стратегічних захисних рімень суб'єктами безпеки.
\end{abstract}

Ключові слова: підприємство, нафтогазова промисловість, економічна безпека, загроза, прогноз, експерт

Постановка проблеми. Політична, економічна та соціальна нестабільність, військові дії на території нашої країни та інші чинники суттєво впливають на умови ведення господарської діяльності більшістю вітчизняних промислових підприємств, зокрема і підприємств нафтогазової промисловості. Сьогодні не лише ефективна діяльність, але й збереження бізнесу залежать від здатності кожного суб'єкта господарювання сформувати власну систему економічної безпеки. Кількість викликів, загроз та ризиків у всіх сферах діяльності зі сторони зовнішнього та внутрішнього середовища $\epsilon$ критично високою, відтак потреба у формуванні методичних засад забезпечення економічної безпеки підприємств нафтогазової промисловості, як орієнтиру для реалізації захисних дій, $є$ особливо гострою.

Рівень економічно безпеки підприємства змінюється безперервно в наслідок взаємодії із зовнішнім середовищем та під впливом внутрішніх процесів. Ця безперервність і вимагає приділення максимальної уваги не лише оцінці рівня економічної безпеки в кожен окремий період часу, але й формуванню прогнозів зміни під впливом ключових загроз як основи для реалізації стратегічних захисних рішень суб'єктами безпеки.

Аналіз останніх досліджень і публікацій. Дослідженню проблеми забезпечення економічної безпеки підприємств різних видів діяльності та розробці питань щодо прогнозування зміни рівня безпеки соціальноекономічних систем приділено увагу у наукових працях таких дослідників як М. М. Караїм [3], Я. В. Котляревського [1; 3-4], Х.О. Мандзіновської [1], О.В. Мельникова [1-2; 4], Т. В. Оля-

(C) Шинкар Світлана Миколаївна, здобувач, Українська академія друкарства, м.Львів нишен [2], Ю. В. Ратушняка [3-4], Е.П. Семенюка [2], В.М. Сеньківського [2], А. М. Штангрета [1; 4-5] та інші.

Віддаючи належне науковій i практичній значущості праць учених, слід зазначити, що у сучасній науковій літературі й практиці господарювання підприємств недостатньо досліджені важливі питання забезпечення економічної безпеки підприємств нафтогазової промисловості.

Формування цілей статті. Метою статті $є$ прогнозування можливої зміни економічної безпеки підприємств нафтогазової промисловості під впливом ключових загроз.

Опис основного матеріалу дослідження. Кожне промислове підприємство характерризується своєю певною організаційною структурою, встановленими горизонтальними та вертикальним зв'язками, організацією інформаційних потоків, системою обліковоаналітичного забезпечення управління суб'єктом господарювання. Формування методичних підходів до прогнозування зміни економічної безпеки промислових підприємств має грунтуватися на тій сукупності загроз, які можна вважати типовими.

Грунтуючись на аналізі фінансовоекономічної діяльності підприємств нафтогазової промисловості були виділені найголовніші загрози іiі економічній безпеці, які наведені в табл. 1.

Для аналізу ситуації були залучені експерти, що мали визначити перспективи галузі та оцінити вплив обраних загроз на іiі розвиток. Результатом оцінювання стало ранжування загроз за рівнем їх впливу на розвиток аналізованої ситуації. На основі цих оцінок в наступному має прийматися рішення про запобігання тим чи іншим негативним явищам. 
Таблиця 1

Сукупність загроз економічній безпеці підприємств нафтогазової промисловості*

\begin{tabular}{|l|c|}
\hline \multicolumn{1}{|c|}{ Назва загрози } & Позначення \\
\hline державна фіскальна політика & $a_{1}$ \\
\hline державна політика щодо регулювання цін на енергоносії & $a_{2}$ \\
\hline стан запасів нафтогазових родовищ & $a_{3}$ \\
\hline споживчий попит на внутрішньому ринку & $a_{4}$ \\
\hline конкурентоспроможність продукції на зовнішніх ринках & $a_{5}$ \\
\hline $\begin{array}{l}\text { наявність ресурсів для буріння нових свердловин та проведення капітальних ремонтів } \\
\text { існуючих }\end{array}$ & $a_{6}$ \\
\hline кваліфікація інженерних і робітничих кадрів & $a_{7}$ \\
\hline
\end{tabular}

*Розроблено автором

У якості експертів залучалися науковці з ВНЗ Львова та Києва та працівники облікових та аналітичних підрозділів промислових підприємств. Необхідно відзначити, що експерт - це спеціаліст у конкретній сфері діяльності, який володіє необхідними знаннями та досвідом, та в стані здійснити аналіз наданої інформації та оцінити об'єкт експертизи в межах своєї компетенції. Слід зауважити, що саме перелічені критерії були взяті автором за основу при залученні експертів.

Подібно до відомих підходів [1, с. 122], експертам запропонували оцінити розвиток ситуації для підприємств нафтогазової промисловості протягом 2018-2022 рр. за реалістичним, песимістичним та оптимістичним сценарієм розвитку подій.

Далі за допомогою методу парних порівнянь експерти порівнювали вплив виділених загроз на розвиток ситуації. Результати порівняння стали підставою побудови квадратних оберненосиметричних матриць парних порівнянь загроз економічній безпеці підприємств. Порядок матриці визначається числом аналізованих загроз (див. табл. 1).

Для оцінки загроз було застосовано шкалу пріоритетів (відносної важливості загроз) наведену в табл. 2.

Таблиця 2

Шкала відносної важливості загроз економічній безпеці промислових підприємств*

\begin{tabular}{|c|c|c|}
\hline Бал & Вимір оцінки & Якісна оцінка \\
\hline 1 & очікувані наслідки від дії загроз рівноцінні & відсутність переваги однієї загрози над іншою \\
\hline 3 & одна загроза дещо переважає іншу за & існує підстава наявності слабкої переваги однієї \\
наслідками & загрози над іншою
\end{tabular}

* Розроблено автором за джерелом [2, с. 103-104]

У табл. 3 узагальнені міркування, якими керувалися експерти, аналізуючи вплив визначених загроз (див. табл. 1) на економічну безпеку підприємств нафтогазової промисловості протягом 2018-2022 pp.

Аналізуючи ситуацію експерти вважали:

- в теорії державна фіскальна політика $a_{1}$ має ставати усе більш гнучкою, якщо держава зацікавлена у подальшому зростанні видобутку та переробленні вітчизняної нафти і газу;

- у сьогоднішніх умовах важко очікувати, що держава відмовиться від політики регулювання цін на енергоносії $a_{2}$, адже це тісно повязане із функціонуванням практично усіх галузей господарювання країни;
- держава зацікавлена у уведення в експлуатацію раніше розвіданих та продовженні експлуатації існуючих родовищ $a_{3}$, якщо такі можливості існують. Усе це тісно пов'язане 3 наявністю ресурсів для буріння нових свердловин та проведення капітальних ремонтів існуючих $a_{6}$;

- для зростання споживчого попиту на внутрішньому ринку $a_{4}$ необхідно пожвавлення ділової активності в державі та зростання добробуту населення, що можливе лише за дуже сприятливого розвитку подій наприкінці аналізованого періоду;

- конкурентоспроможність продукції вітчизняної нафтогазової промисловості на зовнішніх ринках $a_{5}$ пов'язана у першу чергу із їх ціною та 
якістю. Маловірогідним видається поява у власників існуючих підприємств чи зовнішніх інвесторів вільних коштів на реконструкцію існуючих потужностей $a_{6}$ за існуючої нестабільної суспільно-політичної ситуації в країні;
- ситуація $з$ кваліфікованими кадрами в у галузі $a_{7}-$ позитивним для перспектив галузі $\epsilon$ відносно високий рівень оплати праці інженерів і робітників порівняно з підприємствами інших галузей.

Таблиця 3

Вплив загроз на економічну безпеку підприємств нафтогазової промисловості протягом 2018-2022 pp. *

\begin{tabular}{|c|c|c|c|}
\hline \multirow{2}{*}{$\begin{array}{c}\text { Загрози та їх буквенні } \\
\text { позначення } \\
\end{array}$} & \multicolumn{3}{|c|}{ За розвитку ситуації } \\
\hline & реалістичного & песимістичного & оптимістичного \\
\hline $\begin{array}{l}\text { Державна фіскальна політика, } \\
a_{1}\end{array}$ & $\begin{array}{c}\text { податкове навантаження } \\
\text { лишеться незмінним }\end{array}$ & $\begin{array}{c}\text { податкове наван- } \\
\text { таження зростатиме }\end{array}$ & $\begin{array}{l}\text { послаблення по- } \\
\text { даткового тиску }\end{array}$ \\
\hline $\begin{array}{l}\text { Державна політика щодо } \\
\text { регулювання цін на енер- } \\
\text { гоносії, } a_{2}\end{array}$ & \multicolumn{2}{|c|}{$\begin{array}{c}\text { за такий нетривалий період часу маловірогідною } \\
\text { видається кардинальна зміна ситуації }\end{array}$} & $\begin{array}{c}\text { держава відмовиться } \\
\text { від регулювання цін } \\
\text { на енергоносії }\end{array}$ \\
\hline $\begin{array}{l}\text { Стан запасів нафтогазових } \\
\text { родовищ, } a_{3}\end{array}$ & \multicolumn{2}{|c|}{$\begin{array}{c}\text { за такий нетривалий період часу маловірогідною } \\
\text { видається кардинальна зміна ситуації }\end{array}$} & $\begin{array}{c}\text { можливе освоєння } \\
\text { нових родовищ }\end{array}$ \\
\hline $\begin{array}{l}\text { Споживчий попит на } \\
\text { внутрішньому ринку, } a_{4}\end{array}$ & лишеться незмінним & буде зменшуватися & зростатиме \\
\hline $\begin{array}{l}\text { Конкурентоспроможність } \\
\text { продукції на зовнішніх ринках, } \\
a_{5}\end{array}$ & \multicolumn{3}{|c|}{$\begin{array}{c}\text { за такий нетривалий період часу маловірогідною видається кардинальна } \\
\text { зміна ситуації }\end{array}$} \\
\hline $\begin{array}{l}\text { Наявність ресурсів для буріння } \\
\text { нових свердловин та } \\
\text { проведення капітальних } \\
\text { ремонтів існуючих, } a_{6}\end{array}$ & лишеться незмінною & буде зменшуватися & зростатиме \\
\hline $\begin{array}{l}\text { Кваліфікація інженерних } \\
\text { і робітничих кадрів, } a_{7}\end{array}$ & $\begin{array}{c}\text { кваліфікація кадрів } \\
\text { суттєво не покращиться }\end{array}$ & $\begin{array}{c}\text { триватиме відтік } \\
\text { квалфікованих кадрів }\end{array}$ & $\begin{array}{l}\text { ситуація стабілізу- } \\
\text { ється й погіршува- } \\
\text { тися не буде }\end{array}$ \\
\hline
\end{tabular}

*Розроблено автором

Для розв'язання поставленої задачі автор скористалася застосованим для розв'язання інших задач $[2$, с. $224-227 ; 3$, с. $12-13 ; 4$, с. 40-43; 5 , 50-60] методом [6, с. 215-230], а також грунтуючись на відповідних працях [7, с. 224$230 ; 8$, c. 112-119].
Опускаючи виклад найбільш відомого метода наведемо одразу вихідні дані для розрахунків (табл. 4) та результати ранжування загроз економічні безпеці підприємств нафтогазової промисловості за різного розвитку ситуації (табл. 5 i табл. 6).

Таблиця 5

Суми елементів стовпців матриці парних порівнянь загроз економічній безпеці підприємств нафтогазової промисловості $S_{i}$ за розвитку ситуації*

\begin{tabular}{|l|c|c|c|c|c|c|c|}
\hline \multicolumn{1}{|c|}{$a_{i}$} & $a_{1}$ & $a_{2}$ & $a_{3}$ & $a_{4}$ & $a_{5}$ & $a_{6}$ & $a_{7}$ \\
\hline Реалістичного & 7,259 & 7,166 & 7,165 & 7,157 & 7,170 & 7,162 & 7,283 \\
\hline Песимістичного & 7,259 & 7,166 & 7,165 & 7,157 & 7,170 & 7,162 & 7,283 \\
\hline Оптимістичного & 7,157 & 7,165 & 7,259 & 7,162 & 7,166 & 7,170 & 7,283 \\
\hline
\end{tabular}

* Розраховано автором

На основі обчислень суми елементів стовпців матриць парних порівнянь загроз економічній безпеці підприємств нафтогазової промисловості, що були наведені вище (табл. 5), побудуємо зведений рейтинг (табл. 7), що дає можливість порівняти прогнози розвитку ситуації за різних умов.

Таблиця 6

Визначення рівня неузгодженості матриці парних порівнянь, що представлена у вигляді табл. 5*

\begin{tabular}{|l|c|c|c|}
\hline Показник & Найбільше власне число, $k_{\max }$ & Коефіцієнт узгодженості, $C I$ & Рівень неузгодженості, $C R$ \\
\hline $\begin{array}{l}\text { Результати } \\
\text { обчислень }\end{array}$ & 7,195 & 0,032 & 0,025 \\
\hline
\end{tabular}

\footnotetext{
* Розраховано автором
} 


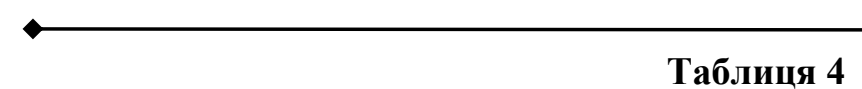

Матриці парних порівнянь загроз економічні безпеці підприємств нафтогазової промисловості за розвитку ситуації*

\begin{tabular}{|c|c|c|c|c|c|c|c|c|}
\hline \multirow{8}{*}{ 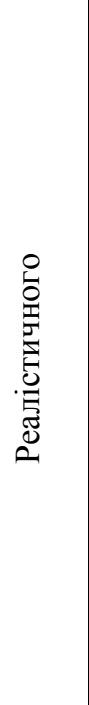 } & $a_{i}$ & $a_{1}$ & $a_{2}$ & $a_{3}$ & $a_{4}$ & $a_{5}$ & $a_{6}$ & $a_{7}$ \\
\hline & $a_{1}$ & 1 & 2 & 4 & 3 & 6 & 5 & 7 \\
\hline & $a_{2}$ & $1 / 2$ & 1 & 3 & 2 & 5 & 4 & 6 \\
\hline & $a_{3}$ & $1 / 4$ & $1 / 3$ & 1 & $1 / 2$ & 3 & 2 & 4 \\
\hline & $a_{4}$ & $1 / 3$ & $1 / 2$ & 2 & 1 & 4 & 3 & 5 \\
\hline & $a_{5}$ & $1 / 6$ & $1 / 5$ & $1 / 3$ & $1 / 4$ & 1 & $1 / 2$ & 2 \\
\hline & $a_{6}$ & $1 / 5$ & $1 / 4$ & $1 / 2$ & $1 / 3$ & 2 & 1 & 3 \\
\hline & $a_{7}$ & $1 / 7$ & $1 / 6$ & $1 / 4$ & $1 / 5$ & $1 / 2$ & $1 / 3$ & 1 \\
\hline \multirow{8}{*}{ 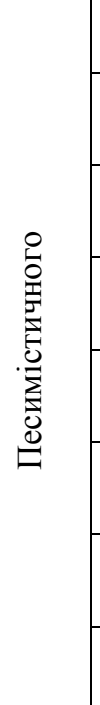 } & $a_{i}$ & $a_{1}$ & $a_{2}$ & $a_{3}$ & $a_{4}$ & $a_{5}$ & $a_{6}$ & $a_{7}$ \\
\hline & $a_{1}$ & 1 & 2 & 4 & 3 & 6 & 5 & 7 \\
\hline & $a_{2}$ & $1 / 2$ & 1 & 3 & 2 & 5 & 4 & 6 \\
\hline & $a_{3}$ & $1 / 4$ & $1 / 3$ & 1 & $1 / 2$ & 3 & 2 & 4 \\
\hline & $a_{4}$ & $1 / 3$ & $1 / 2$ & 2 & 1 & 4 & 3 & 5 \\
\hline & $a_{5}$ & $1 / 6$ & $1 / 5$ & $1 / 3$ & $1 / 4$ & 1 & $1 / 2$ & 2 \\
\hline & $a_{6}$ & $1 / 5$ & $1 / 4$ & $1 / 2$ & $1 / 3$ & 2 & 1 & 3 \\
\hline & $a_{7}$ & $1 / 7$ & $1 / 6$ & $1 / 4$ & $1 / 5$ & $1 / 2$ & $1 / 3$ & 1 \\
\hline \multirow{2}{*}{ 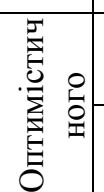 } & $a_{i}$ & $a_{1}$ & $a_{2}$ & $a_{3}$ & $a_{4}$ & $a_{5}$ & $a_{6}$ & $a_{7}$ \\
\hline & $a_{1}$ & 1 & 2 & $1 / 3$ & 3 & $1 / 2$ & 4 & 5 \\
\hline
\end{tabular}

\begin{tabular}{|c|c|c|c|c|c|c|c|c|}
\hline$a_{2}$ & $1 / 2$ & 1 & $1 / 4$ & 2 & $1 / 3$ & 3 & 4 \\
\hline$a_{3}$ & 3 & 4 & 1 & 5 & 2 & 6 & 7 \\
\hline$a_{4}$ & $1 / 3$ & $1 / 2$ & $1 / 5$ & 1 & $1 / 4$ & 2 & 3 \\
\hline$a_{5}$ & 2 & 3 & $1 / 2$ & 4 & 1 & 5 & 6 \\
\hline$a_{6}$ & $1 / 4$ & $1 / 3$ & $1 / 6$ & $1 / 2$ & $1 / 5$ & 1 & 2 \\
\hline$a_{7}$ & $1 / 5$ & $1 / 4$ & $1 / 7$ & $1 / 3$ & $1 / 6$ & $1 / 2$ & 1 \\
\hline
\end{tabular}

* Розраховано автором

Перше, що кидається в очі (табл. 7), реалістичний та песимістичний розвиток ситуації для підприємств галуз, - це одне й те саме, тобто експерти не передбачають кардинальної зміни ситуації за найближчі п'ять років. Усі експерти сходяться на думці, що основною причиною цього $є$ військовий конфлікт на сході України.

Через падіння доходів домогосподарств попит на внутрішньому ринку на продукцію підприємств нафтогазової промисловості $a_{4}$ постійно зменшується [9-10], як наслідок цього відсутність ресурсів для буріння нових свердловин та проведення капітальних ремонтів існуючих $a_{6}$ вийшла на другий рівень загроз за важливістю впливу на ситуацію в галузі. Результати обчислень підтверджують також існуючи дані [11] про критичний стан запасів вітчизняних нафтогазових родовищ $a_{3}$. Вплив держави на ситуацію в галузі (державна політика щодо регулювання цін на енергоносії, $a_{2}$ та державна фіскальна політика, $a_{1}$ ) не $\epsilon$ критичним. Це може видатися дещо дивним, але якщо врахувати міркування експертів (див. табл. 3), що найближчі п'ять років ситуація буде погіршуватися чи залишиться незмінною зрозумілим стає неможливість органів державної влади кардинально покращити ситуацію в галузі.

Таблиця 7

Вплив загроз на економічну безпеку підприємств нафтогазової промисловості протягом 2018-2022 pp. *

\begin{tabular}{|c|c|c|}
\hline \multirow{2}{*}{$\begin{array}{c}\text { Рейтин } \\
\text { (рівень } \\
\text { загрози) }\end{array}$} & реалістичного & За розвитку ситуації \\
\cline { 2 - 4 } & песимістичного & оптимістичного \\
\hline 7 & Споживчий попит на внутрішньому ринку, $a_{4}$ & Державна фіскальна політика, $a_{1}$ \\
\hline 6 & $\begin{array}{c}\text { Наявність ресурсів для буріння нових свердловин та } \\
\text { проведення капітальних ремонтів існуючих, } a_{6}\end{array}$ & $\begin{array}{c}\text { Споживчий попит на } \\
\text { внутрішньому ринку, } a_{4}\end{array}$ \\
\hline 5 & Стан запасів нафтогазових родовищ, $a_{3}$ & $\begin{array}{c}\text { Державна політика щодо } \\
\text { регулювання цін на енергоносії, } a_{2}\end{array}$ \\
\hline 4 & Державна політика щодо регулювання цін на енергоносії, \\
$a_{2}$ & $\begin{array}{c}\text { Конкурентоспроможність } \\
\text { продукції на зовнішніх ринках, } a_{5}\end{array}$ \\
\hline
\end{tabular}




\begin{tabular}{|c|c|c|}
\hline & & Продовження табл. 7 \\
\hline 3 & $\begin{array}{c}\text { Конкурентоспроможність продукції на зовнішніх ринках, } \\
\qquad a_{5}\end{array}$ & $\begin{array}{c}\text { Наявність ресурсів для буріння } \\
\text { нових свердловин та проведення } \\
\text { капітальних ремонтів існуючих, } a_{6}\end{array}$ \\
\hline 2 & Державна фіскальна політика, $a_{1}$ & $\begin{array}{c}\text { Стан запасів нафтогазових } \\
\text { родовищ, } a_{3}\end{array}$ \\
\hline 1 & \multicolumn{2}{|c|}{ Кваліфікація інженерних і робітничих кадрів, $a_{7}$} \\
\hline
\end{tabular}

За оптимістичного розвитку ситуації: припинення воєнних дій та пожвавлення економіки в органів державної влади може виникнути бажання збільшити державне втручання (державна політика щодо регулювання цін на енергоносії $a_{2}$ та державна фіскальна політика $a_{1}$ ), хоча насправді податкове втручання мало би зменшуватися. Споживчий попит $a_{4}$ має зростати, тож у рейтингу загроз він має втрачати свої позиції, що ми й бачимо в табл. 3. За таких умов конкурентоспроможність продукції на зовнішніх ринках $a_{5}$ має зростати, відповідно мають з'являтися ресурси для буріння нових свердловин та проведення капітальних ремонтів існуючих, $a_{6}$. За оптимістичного розвитку подій бачимо, що стан запасів нафтогазових родовищ, $a_{3}$ не $\epsilon$ критичною загрозою розвитку підприємств галузі, адже за позитивної динаміки змін у галузі мають інтенсифікуватися геологорозвідувальні роботи та зростатиме експорт нафтопродуктів для перероблення на вітчизняних підприємствах.

Висновки i перспективи подальших досліджень. Поточна ситуація, що складається

на більшості вітчизняних промислових підприємствах, вимагає зосередження максимальної уваги на вирішенні проблеми забезпечення безпеки.

Належний рівень економічної безпеки уможливлює як збереження бізнесу, так i формування підгрунтя для сталого розвитку певного суб' єкта господарювання.

На економічну безпеку підприємств нафтогазової промисловості впливають як зовнішні, так і внутрішні загрози, протидія яким можлива за умов своєчасної реалізації захисних заходів.

Інформаційним підгрунтям для розроблення сукупності стратегічних захисних заходів повинні стати результати проведеного дослідження та запропонованого методичного забезпечення формування реалістичного, песимістичного та оптимістичного прогнозів впливу загроз на економічну безпеку підприємств нафтогазової промисловості.

Подальшого наукового дослідження потребує проблема формування стратегії захисту підприємств нафтогазової промисловості.

\section{ПЕРЕЛІК ВИКОРИСТАНИХ ДЖЕРЕЛ}

1. Фінансова безпека машинобудівного підприємства : Методичні засади формування та забезпечення / [Х. О. Мандзіновська, А. М. Штангрет, Я. В. Котляревський, О. В. Мельников]. - Львів : Укр. акад. друкарства, 2016. - 240 с.

2. Екологізація суспільства : Соціальна роль та моделювання / [Е. П. Семенюк, Т. В. Олянишен, В. М. Сеньківський, О. В. Мельников, Я. В. Котляревський]. - Львів: Укр. акад. друкарства, 2012. - 320 с.

3. Котляревский Я. В. Ієрархічне впорядкування зовнішніх загроз як основа застосування антикризових технологій в управлінні економічною безпекою машинобудівного підприємства / Я.В.Котляревський, М. М. Караїм, Ю. В. Ратушняк // Інвестиції: Практика та досвід. — 2015. — № 24. — С. 11-15

4. Котляревский Я. В. Ієрархічне впорядкування факторів, що стримують або стимулюють розвиток інформаційної сфери в Україні / Я.В.Котляревський, О.В.Мельников, А.М.Штангрет, Ю.В. Ратушняк // Наук. пр. Науково-дослід. фін. ін-ту. — 2016. - Вип. 2 (75). — С. 39-52

5. Обліково-аналітичне забезпечення управління економічною безпекою підприємств/ за заг. ред. А. Штангрета. - Львів: Укр. акад. друкарства, 2017. — 240 с.

6. Саати Т. Принятие решений. Метод анализа иерархий : пер. с англ. / Т. Саати. - М. : Радио и связь, 1993. $-315 \mathrm{c}$.

7. Лямец В. И. Системный анализ. Вводный курс / В. И. Лямец, А. Д. Тевяшев. — 2-е изд., перераб. и доп. Х. : ХНУРЭ, 2004. — 448 с. — (Прикладная математика)

8. Харари Ф. Теория графов : пер. с англ. / Ф. Харари. — М. : Мир, 1973. — 302 с.

9. Енергетична галузь України: підсумки 2015 року - Центр Разумкова, 2016; НАК «Нафтогаз України» [Електронний pecypc]. Режим доступу http://www.naftogaz.com/www/3/nakweb.nsf/0/74B2346ABA0CBC69C22570D80031A365?OpenDocument

10. Маркевич К. Глобальні енергетичні тренди крізь призму національних інтересів України : Аналітична доповідь [Електронний ресурс] / К. Маркевич, В. Омельченко. - Режим доступу : http://www.razumkov.org.ua/images/broshura/2016_ENERGY-S.pdf 
11. Загороднюк П. Природній газ в Україні. Традиційні джерела [Електронний ресурс] / П. Загороднюк. — Режим доступу : http://ua-energy.org/upload/files/Pavlo_Zagorodniuk_Presen-tation_Ua.pdf

\section{REFERENCES}

1. Mandzinovs'ka, Kh. O. Shtanhret, A. M. Kotlyarevs'kyy, Ya. V. Mel'nykov, O. V. (2016), Finansova bezpeka mashynobudivnoho pidpryyemstva : Metodychni zasady formuvannya ta zabezpechennya [Financial safety of the machine-building enterprise: Methodological principles of formation and provision]. Ukr. akad. drukarstva, L'viv, [in Ukrainian].

2. Semenyuk, E. P., Olyanyshen, T. V., Sen'kivs'kyy, V. M., Mel'nykov, O. V., Kotlyarevs'kyy, Ya. V. (2012), Ekolohizatsiya suspil'stva : Sotsial'na rol' ta modelyuvannya [Ecologization of society: Social role and modeling]. Ukr. akad. drukarstva, L'viv, [in Ukrainian].

3. Kotlyarevskyy, Ya. V., Karayim, M. M., Ratushnyak, Yu. V. (2015), Iyerarkhichne vporyadkuvannya zovnishnikh zahroz yak osnova zastosuvannya antykryzovykh tekhnolohiy $\mathrm{v}$ upravlinni ekonomichnoyu bezpekoyu mashynobudivnoho pidpryyemstva [Hierarchical ordering of external threats as the basis of application of anti-crisis technologies in management of economic safety of machine-building enterprise]. Investytsiyi: Praktyka ta dosvid. 2015 , Vol. 24: 11-15 [in Ukrainian].

4. Kotlyarevskyy, Ya. V., Mel'nykov, O. V., Shtanhret, A. M., Ratushnyak, Yu. V. (2016), Iyerarkhichne vporyadkuvannya faktoriv, shcho strymuyut' abo stymulyuyut' rozvytok informatsiynoyi sfery v Ukrayini [Hierarchical ordering of factors that restrain or stimulate the development of the information sphere in Ukraine]. Nauk. pr. Naukovo-doslid. fin. in-tu. 2016, Vol. 2(75): 39-52 [in Ukrainian].

5. Shtanhret, A. M. (2017), Oblikovo-analitychne zabezpechennya upravlinnya ekonomichnoyu bezpekoyu pidpryyemstv [Accounting and analytical support for managing economic security of enterprises], Ukr. akad. drukarstva, L'viv, [in Ukrainian].

6. Saati, T. (1993), Prinjatie reshenij. Metod analiza ierarhij [Making decisions. Method for analyzing hierarchies], Radio i svjaz', Moskva, Rossijskaja Federacija [in Russian].

7. Ljamec, V. I., Tevjashev, A. D. (2004), Sistemnyj analiz. Vvodnyj kurs [System analysis. Introductory course], HNURJe, Harkiv, [in Ukrainian].

8. Harari, F. (1973), Teorija grafov [Graph Theory], Mir, Moskva, Rossijskaja Federacija [in Russian].

9. Enerhetychna haluz' Ukrayiny: pidsumky 2015 roku — Tsentr Razumkova [Energy sector of Ukraine: the results of 2015 - Razumkov Center]. NAK «Naftohaz Ukrayiny», Retrieved from: http://www.naftogaz.com/www/3/nakweb.nsf/0/74B2346ABA0CBC69C22570D80031A365?OpenDocument

10. Markevych, K., Omel'chenko, V. (2017), Hlobal'ni enerhetychni trendy kriz' pryzmu natsional'nykh interesiv Ukrayiny : Analitychna dopovid' [Global energy trends through the prism of Ukraine's national interests: An analytical report], Retrieved from: http://www.razumkov.org.ua/images/broshura/2016_ENERGY-S.pdf

11. Zahorodnyuk, P. (2017), Pryrodniy haz v Ukrayini. Tradytsiyni dzherela [Natural gas in Ukraine. Traditional sources], Retrieved from: http://ua-energy.org/upload/files/Pavlo_Zagorodniuk_Presen-tation_Ua.pdf

Одержано 12.03.2018 p. 